\title{
Analysis of polyhydroxybutrate and bioplastic production from microalgae
}

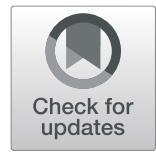

Sayeda M. Abdo ${ }^{*}$ and Gamila H. Ali

\begin{abstract}
Background: Algae manufacture a diversity of base materials that can be used for bioplastics assembly. The most essential compounds are carbohydrates and hydrocarbons. Polyhydroxybutyrate (PHB) is a polymer belonging to the polyester class that is of interest as bio-derived and biodegradable plastics.

Results: In this study, three microalgal strains in addition to two microalgal biomass collected from high-rate algal ponds (HRAP) were used to detect their ability to produce polyhydroxybutrate for bioplastic production. The results showed that among the selected strains, Microcystis aeruginosa has the highest polyhydroxybutrate concentration $\left(0.49 \pm 0.5 \mathrm{mg} \mathrm{mL}^{-1}\right)$. However, the biomass collected from the high-rate algal pond dominated with Microcystis sp. showed a higher concentration $\left(0.7 \pm 0.6 \mathrm{mg} \mathrm{mL}^{-1}\right)$.

Conclusion: The biomass collected from the high-rate algal pond dominated with Microcystis sp. was used for producing bioplastic since it has the highest concentration of PHB. Referring to plasticizing capacity, elongation at break (\%) for algal biomass was 530\% which was higher than that detected in blank which was 307\%. So, it was obvious that the algal bioplastic has good plasticizing capacity.
\end{abstract}

Keywords: Polyhydroxybutrate, Bioplastic, Microalgae, High-rate algal pond, Biomass

\section{Introduction}

An increased usage of plastics continues, and production will need to keep up with the demand. Traditional petroleum-derived plastics made of synthetic polymers are engaged in many traditions; they cause a high price of the huge amount of consumed energy during manufacture and their resistance to decay. Conventional plastics harm the environment since (1) they are made of crude oil which is a diminishing natural source, (2) they do not undergo bacterial decomposition so that landfills only preserve them for centuries; and (3) their incineration releases noxious chemicals (Zeller et al. 2013). Bioplastics from natural feedstocks is a good alternative for usual plastic since bioplastic has biodegradable properties. Carbohydrate fractions of biomass like starch and cellulose from corn, wheat, and potato are the basic raw material for conversion into bioplastics (Orliac and Silvestre 2003; Zhang et al. 2003; Jerez et al. 2007). The biggest challenge in the production of bioplastic is the source of biomass used where there will be a competition between food and feed

\footnotetext{
* Correspondence: sayedamohammed2015@gmail.com

Water Pollution Research Department, National Research Center, Giza 12622, Egypt
}

applications since these crops consume large amounts of petroleum products in their life cycle (National Renewable Energy Laboratory 2007). Microalgal biomass can be used for producing bioplastics, using the biomass directly or its secondary metabolites (Rahman and Miller 2017; Becker 2007).

Using high-rate algal ponds (HRAP) for algal biomass production are more appropriate than predictable food crops, because these systems remediate water for further use and can be grown in urban environments or on nonarable land, which would not be suitable for conventional food crop production. Therefore, microalgae represent an interesting source to improve the sustainability of bioplastic production and in improving water supplies during production (Okada 2002; Stevens 2002).

The PHB content of algal biomass enhances the recyclable property of plastic, where it decreases the quantity of petroleum used in plastic production. Biodegradability and biocompatibility which match to petroleum polymers are the principal strengths of PHB making them applicable in industrial, medicinal, agricultural, and diverse fields. The piezoelectric property of $\mathrm{PHB}$ is used in manufacturing a variety of sensors to determine pressure, sound, light, etc., 


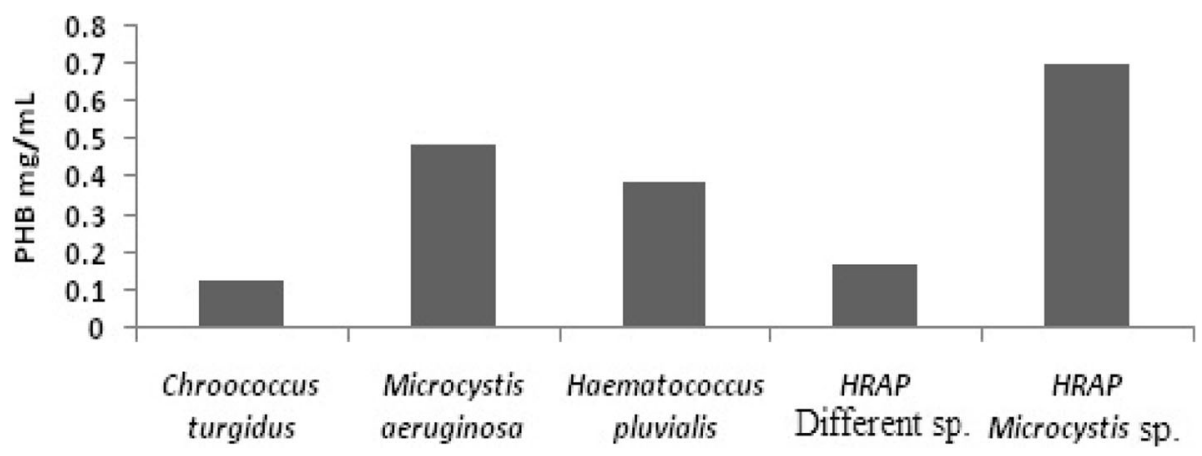

Fig. 1 Polyhydroxybutrate concentration in different microalgal biomass

and in developing audio equipment (Mohammed and Aburas 2016; Aguilar and San Rom 2014). PHB has also been used in developing nano-complex films and nanotubes with improved material properties (Yun et al. 2008).

PHB films are used to pack urea fertilizers and insecticides, which when used in the agricultural land can free the fertilizers or insecticides in a controlled mode as the soil microbial community gradually degrade the PHB film (Aguilar and San Rom 2014). The next major application for PHB is in the medical field, where PHB is used as scaffolds, bone plates, media for slow release of drugs, and surgical sutures (Steinbüchel and Füchtenbusch 1998). PHB has been used in bone renewal treatments and nerve injury, also due to its piezoelectric nature (Misra et al. 2006). Blending of PHB with inorganic phases results in bioactive composites of higher properties that can be used in tissue engineering applications (Chen 2009). Many different types of bacteria and algae produce polyhydroxybutyrate (PHB) as food storage material (Falcone 2004).

From this point of view, the aim of this study is to figure out the possibility of using microalgal biomass as a source polyhydroxybutrate and bioplastic production.

\section{Method for PHB quantification}

$0.01 \mathrm{~g}$ of commercial PHB is weighed in a glass tube and dissolved in $10 \mathrm{ml}$ chloroform by heating in a water bath $\left(65-70{ }^{\circ} \mathrm{C}\right)$ till the solution is clear. This gives a $1 \mathrm{mg} / \mathrm{ml}$ PHB stock solution. The tube is capped with a glass stopper during heating. One milliliter of the $1 \mathrm{mg} / \mathrm{ml}$ stock is pipetted into a fresh tube with $9 \mathrm{ml}$ chloroform to make a $100 \mu \mathrm{g} \mathrm{ml}^{-1} \mathrm{PHB}$ stock, and the tubes are heated $\left(65-70{ }^{\circ} \mathrm{C}\right)$ then vortexes. A $10 \mathrm{ml}$ concentration of $\mathrm{H}_{2} \mathrm{SO}_{4}$ is added to the tubes which were capped with glass stoppers. The tubes are heated in boiling water bath $\left(94-96^{\circ} \mathrm{C}\right)$ for $20 \mathrm{~min}$ for complete conversion of PHB to crotonic acid. One milliliter of this sample is then transferred to a silica cuvette for spectrophotometry. The scan program of the spectrophotometer software is used, and the samples are scanned between 190 and $800 \mathrm{~nm}$ of the spectrum for a peak at $235 \mathrm{~nm}$ which corresponds to crotonic acid. Concentrated $\mathrm{H}_{2} \mathrm{SO}_{4}$ is used as the zero (blank). The respective absorbance at $235 \mathrm{~nm}$ vs the respective PHB weight was plotted to get the standard curve (Bonarteseva and Myshkina 1985).

\section{Method for PHB extraction from algal biomass}

One gram of algal biomass (whatever isolated test organism or collected from HRAP) was suspended in sterile water and homogenized then allowed for mixing with a vortex. From $2 \mathrm{ml}$ of suspension, $2 \mathrm{ml}$ of $2 \mathrm{~N} \mathrm{HCL}$ was added then heated for $2 \mathrm{~h}$ in a water bath. Then, the tube was centrifuged at $6000 \mathrm{rpm}$ for $20 \mathrm{~min}$ and $5 \mathrm{ml}$ of chloroform is added and left overnight at $28^{\circ} \mathrm{C}$ on a shaker at $150 \mathrm{rpm}$. Then, it was centrifuged at $2000 \mathrm{rpm}$ for $20 \mathrm{~min}$, extracted with $1 \mathrm{ml}$ of chloroform, and dried at $40{ }^{\circ} \mathrm{C}$. Five milliliters of concentrated sulfuric acid was added to the tube and the mixture was heated at $100{ }^{\circ} \mathrm{C}$ in a water bath for $20 \mathrm{~min}$. After the PHB crystals were converted to crotonic acid. The PHB content was measured at $235 \mathrm{~nm}$ in UV spectrophotometer against sulfuric acid blank. From the cell dry weight and PHB content, the percentage of PHB produced by the organisms was calculated (Bonarteseva and Myshkina 1985).

\section{Bioplastic ingredients}

The algal biomass bioplastic ingredients include $2.25 \mathrm{~g}$ sorbitol, 2.25 g gelatin, 2.25 g Microcystisflos aqua, and 75 $\mathrm{ml}$ of $2 \%$ glycerol solution. All the ingredients were mixed well, and the mixture was heated to $95^{\circ} \mathrm{C}$. The mixture was stirred, while being heated, and once it is at the right temperature, the heat was removed while continuously stirring. The mixture was poured into a dried pan and spread out to let it dry. The time required for separation of plastic is depending on the temperature of the room; it may take several days. After complete drying, the bioplastic was separated from the pan (Stevens 2002).

The commercial petrol-based plastic was prepared to compare with the algal biomass bioplastic. The ingredients include $4.5 \mathrm{~g}$ sorbitol, $2.25 \mathrm{~g}$ gelatin, and $75 \mathrm{ml}$ of $2 \%$ glycerol solution. The bioplastic and commercial 
Table 1 Mechanical properties of bioplastic produced from HRAP microalgal biomass

\begin{tabular}{llll}
\hline Sample & $\begin{array}{l}\text { Tensile } \\
\text { strength } \\
\mathrm{MPa}\end{array}$ & $\begin{array}{l}\text { Elongation at } \\
\text { tensile strength } \\
\%\end{array}$ & $\begin{array}{l}\text { Elongation } \\
\text { at break } \\
\%\end{array}$ \\
\hline Blank & 1.35 & 290 & 307 \\
HRAP Microcystis sp. & 1.62 & 530 & 541 \\
\hline
\end{tabular}

petrol based plastic was compared with one another. The plasticizing capacity, the moldable property of bioplastic and commercial plastic was analyzed.

\section{SEM analysis}

Scanning electron microscopy (JEOL JXA 840A), microanalyzer electron probe, was used to estimate the particle shapes and also to show the distribution of bioplastic sample.

\section{Mechanical properties}

The plasticizing capacity, the moldable property of bioplastic and commercial plastic, was analyzed using ASTM: D412 for the determination of mechanical properties using Zwick/Roell Tensile Testing Machine (model-Z010).

\section{Results}

Selected microalgal strains were grown for 15 days, dried at $60^{\circ} \mathrm{C}$, and subjected to PHB extraction. Results showed that Microcystis aeruginosa has the highest concentration which is $0.49 \pm 0.5 \mathrm{mg} \mathrm{ml}^{-1}$ followed by Haematococcus pluvialis at $0.39 \pm 0.42 \mathrm{mg} \mathrm{ml}^{-1}$ (Fig. 1). Since producing bioplastic on a large scale needs high biomass content, the use of algal biomass collected from HRAP for domestic wastewater treatment was recommended since the biomass produced from HRAP reached $2 \mathrm{~g} \mathrm{~L}^{-1}$ and need no addition of nutrients. Two different algal biomasses were used. As indicated in Fig. 1, biomass dominated with Microcystis sp. showed the highest concentration among the selected strains and the other algal biomass, where the concentration reached $0.7 \mathrm{mg} \mathrm{ml}^{-1} \pm 0 . .6$.

\section{Algal biomass and bioplastic SEM}

As seen in SEM micrographs, microalgal biomass has quite small cell sizes which were found to be less than $50 \mathrm{~mm}$ (Fig. 2a). This small cell size contributes to better distribution in the medium when mixed with other ingredients, making this algal biomass more suitable for bioplastic and film applications in which particle size is an important criterion. The morphology of fracture surfaces for plasticized microalgal bioplastic showed very little change in the overall topography of the microalgal plastics (Fig. 2b).

\section{Mechanical properties of bioplastic}

The bioplastic and plastic were compared for tensile properties such as stress and elongation at maximum load. The results showed that the tensile stress detected in algal biomass was 1.35 and 1.62 Mpa for blank and algal biomass, respectively. In addition, elongation at break (\%) for algal biomass was $530 \%$ which was higher than that detected in blank which was $307 \%$ (Table 1). It is obvious that the algal bio plastic has good plasticizing capacity.

\section{Discussion}

Bioplastic which in chemistry is called polyhydroxyalkanoate (PHA) can replace plastic in many applications (Eggersdorfer et al. 1992). Many fat polymer materials are belonging to the PHA polymers and poly- $\beta$-hydroxyl butyrate (PHB) which is one of the most known PHA.

In this study, the addition of sodium acetate to the cultivation media of the selected strains affected the production of polyhydroxybutrate. These results correlated with other results where the measurement of PHB by chemical analysis in Chlorogloea fritschii was done in the presence of sodium acetate (Carr 1966). The concentration detected in algal biomass collected from HRAP reached $0.7 \mathrm{mg} \mathrm{ml}^{-1} \pm 0.6$. These results were in harmony with that found by (Vincenzini et al. 1990) who found that the concentration of PHB detected in Spirulina culture was $0.7 \mathrm{mg} \mathrm{g}^{-1}$. As mentioned before that the presence of sodium acetate enhances PHB production, the collected algal biomass does not contain sodium acetate, but the organic load is very high since it is growing in municipal wastewater.
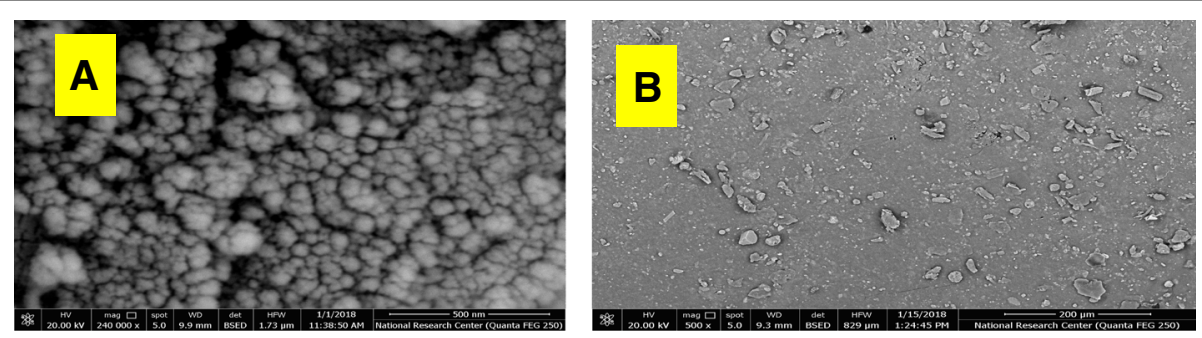

Fig. 2 SEM micrographs of a microalgal biomass and $\mathbf{b}$ bioplastic 
The results showed that the dry cell weight of algal biomass dominated with Microcystis sp. was $0.2 \mathrm{~g} \mathrm{~L}^{-1}$ and the PHB amount was $0.0067 \mathrm{~g} \mathrm{~L}^{-1}$. The percentage of PHB is calculated and was found to be $4.38 \%$. It was found that the PHB detected in Spirulina platensis was $0.006 \mathrm{~g} \mathrm{~L}^{-1}$ with a percentage of $5.18 \%$ (Maheswari and Ahilandeswari 2011).

The SEM micrograph showed small sizes, and this small cell size contributes to an improved distribution of the algal biomass in the medium when blended with other ingredients, making this algal biomass more suitable for plastic and film applications in which particle size is an important criterion. It is obvious that the algal bioplastic has a good plasticizing capacity.

\section{Conclusion}

- Algal bioplastics may have a vital role as an environmentally friendly, biodegradable alternative compared to ordinary plastics.

- The efficiency of PHB production using microalgal biomass collected from high-rate algal pond may reduce the operational costs, making it an interesting prospect for many industrial, therapeutic, and diagnostic applications.

- Using algal biomass collected from high-rate algal pond could be a low-cost, sustainable solution bioplastic production.

- The production of algal bioplastics is still under research and is far from commercialization.

- The significance of algae in bioplastics industry will make algae bio plastics a reality in the near future.

\section{Acknowledgments}

The authors would like to express their appreciation to the "Academy of Scientific Research and Technology (ASRT)" for the financial support through Project grant number 1343 entitled "Novel approach to maximize the use of stabilization pond in Egypt: a model for water, energy food nexuses."

\section{Funding}

This work was done in the National Research Centre, Egypt.

\section{Availability of data and materials}

Not applicable

\section{Authors' contributions}

SMA performed the experimental work, and GHA was a major contributor in writing the manuscript and revised the results. Both authors read and approved the final manuscript.

Ethics approval and consent to participate

Not applicable

\section{Consent for publication}

Not applicable

\section{Publisher's Note}

Springer Nature remains neutral with regard to jurisdictional claims in published maps and institutional affiliations.

Received: 28 August 2018 Accepted: 15 May 2019

Published online: 18 June 2019

\section{References}

Aguilar MR, San Rom J (2014) Smart polymers and their applications. Smart polymers and their applications. https://doi.org/10.1533/9780857097026

Becker EW (2007) Micro algae as a source of protein. Biotechnol Adv 25:207-210. https://doi.org/10.1016/j.biotechadv.2006.11.002

Bonarteseva GA, Myshkina VL (1985) Fluorescence intensity of strain of nodule bacteria (Rhizobium meliloti and Rhizobium Phaeseoli) differing in activity, grown in the presence of the lipophilic vial stain phosphine. J Microbiol 54: $535-541$

Carr NG (1966) The occurrence of poly-p-hydroxybutyrate in the blue-green alga, Chlorogloea fritschii. Biochim Biophys Acta 120:308-3 10

Chen G-Q (2009) A microbial polyhydroxyalkanoates (PHA) based bio- and materials industry. Chem Soc Rev 38(8):2434. https://doi.org/10.1039/ b812677c

Eggersdorfer M, Meyer J, Eckes P (1992) Use of renewable resources for nonfood material. FEMS Microbiol Rev 103:355-364

Falcone DB (2004) Biodegradable plastic in the environment. M.Sc., thesis. UFSCar, Sao Paulo

Jerez A, Partal P, Martínez I, Gallegos C, Guerrero A (2007) Protein-based bioplastics: effect of thermo-mechanical processing. Rheol Acta 46:711-720. https://doi.org/10.1007/s00397-007-0165-z

Maheswari NU, Ahilandeswari K (2011) on Co Co. Res. Environ. Life Sci 4(3):133136

Misra SK, Valappil SP, Roy I, Boccaccini AR (2006) Polyhydroxyalkanoate (PHA)/ inorganic phase composites for tissue engineering applications. Biomacromolecules 7(8):2249-2258

Mohammed M, Aburas A (2016) Degradation of poly (3-hydroxybuthyrate) using Aspergillus oryzae obtained from uncultivated soil. Life Sci J 13(3):51-56. https://doi.org/10.7537/marslsj13031607

National Renewable Energy Laboratory. (2007). National Solar Radiation Database 1991 - 2005 Update : User's Manual. Task No. PVA7.6102, (April), 472. doi: https://doi.org/10.2172/901864.

Okada M (2002) Chemical syntheses of biodegradable polymers. Prog Polymer Sci (Oxford) 27(1):87-133. https://doi.org/10.1016/\$0079-6700(01)00039-9

Orliac O, Silvestre F (2003) Microwave esterification of sunflower proteins in solvent-free conditions. Bioresour Technol 87(1):63-68. https://doi.org/10. 1016/S0960-8524(02)00200-6

Rahman A, Miller CD (2017) Chapter 6 - microalgae as a source of bioplastics. Algal Green Chemistry. https://doi.org/10.1016/B978-0-444-63784-0.00006-0

Steinbüchel A, Füchtenbusch B (1998) Bacterial and other biological systems for polyester production. Trends Biotechnol. https://doi.org/10.1016/S01677799(98)01194-9

Stevens ES (2002) Green plastics: an introduction to the new science of biodegradable plastics. Princeton University Press, Princeton

Vincenzini M, Sili C, Philippis RDE, Ena A, Materassi R (1990) Occurrence of polybeta-hydroxybutyrate in Spirulina species. J Bacteriol 172(5):2791-2792

Yun SI, Gadd GE, Latella BA, Lo V, Russell RA, Holden PJ (2008) Mechanical properties of biodegradable polyhydroxy alkanoates/single wall carbon nanotube nanocomposite films. Polym Bull 61(2):267-275. https://doi.org/10. 1007/s00289-008-0936-4

Zeller MA, Hunt R, Jones A, Sharma S (2013) Bioplastics and their thermoplastic blends from Spirulina and Chlorella microalgae. J Appl Polym Sci. https://doi. org/10.1002/app.39559.

Zhang L, Chen P, Huang J, Yang G, Zheng L (2003) Ways of strengthening biodegradable soy-dreg plastics. J Appl Polym Sci 88(2):422-427. https://doi. org/10.1002/app.11718

\section{Competing interests}

The authors declare that they have no competing interests. 